
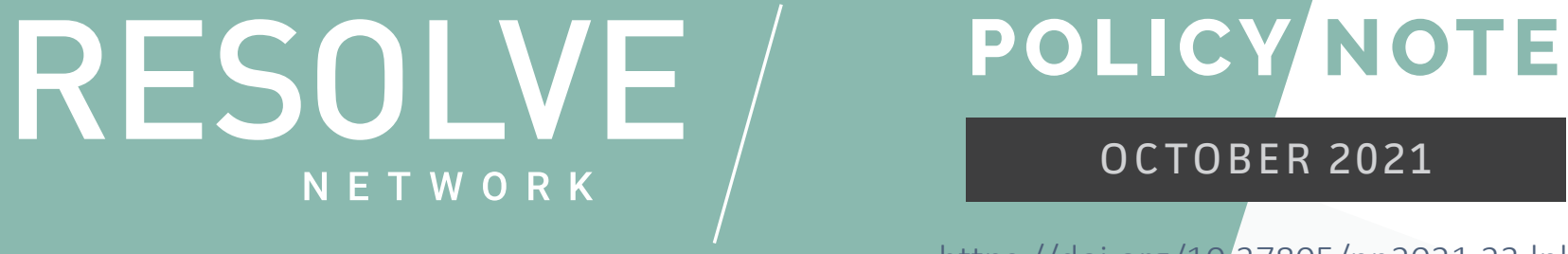

https://doi.org/10.37805/pn2021.23.Ipbi

\title{
TOWARDS LOCAL APPROACHES AND INCLUSIVE PEACEBUILDING IN SOUTH SUDAN:
}

\author{
EMMACULATE ASIGE LIAGA \\ LEARNING FROM LOCAL \\ PEACEBUILDING APPROACHES
}

${ }^{66}$ Local voices, perspectives, and strategies form a crucial niche for peacebuilding interventions and actors, in understanding the root causes and solutions of communal and locally driven Sub-Saharan civil conflicts."

\section{FAST FACTS Context}

$\rightarrow$ Peacebuilding architecture in Africa is shifting towards a focus on local peacebuilding actors as significant contributors to sustainable and durable peace.

$\rightarrow$ In post-conflict South Sudan, the ethnic-based nature of conflict has led to the recognition of various strategies which have been used and practiced by local actors and can be incorporated into contemporary strategies of international peacebuilding actors to transfer agency and ownership of peace to the victims of war.

$\rightarrow$ Non-governmental organizations, within middle-level peacebuilding organizations still maintain a hierarchical partnership perpetuated by the lack of capacity within South Sudanese NGOs and a rigid and ever shrinking funding structure.
Peacebuilding is at a crossroads in Sub-Saharan Africa. The past two decades have witnessed a transition from post-Cold War peace processes shaped by state-centric discourses of liberal institutionalism ${ }^{1}$ to a resurgence of interest in the "local," 2 involving a re-engaging of local communities' concerns, ownership of processes, and capacities. ${ }^{3}$ These approaches, including the micro

1 Meera Sabaratnam, "Avatars of Eurocentrism in the Critique of the Liberal Peace," Security Dialogue 44, no. 3 (2013): 259-278, https:// doi.org/10.1177/0967010613485870.

2 Andreas T. Hirblinger and Claudia Simons, "The good, the bad, and the powerful: Representations of the 'local' in peacebuilding," Secu rity Dialogue 46, no. 5 (2015): 422-439, https://doi.org/10.1177/0 967010615580055

3 Mathijs Van Leeuwen, Joseph Nindorera, Jean-Louis Kambale Nzw eve, and Corita Corbijn, "The 'local turn' and notions of conflict and peacebuilding-Reflections on local peace committees in Burundi and eastern DR Congo," Peacebuilding 8, no. 3 (2020): 279-299, https://doi.org/10.1080/21647259.2019.1633760. 
theoretic turn, ${ }^{4}$ local turn perspectives, ${ }^{5}$ African Peacebuilding, ${ }^{6}$ and decolonial peace theories ${ }^{7}$ explore the space beyond the liberal peace dimensions in research, policy, and practice, arguing that local actors can and must be included in international and governmental efforts to manage conflict. $^{8}$

The consensus is that local actors must be included in conflict management and legitimate peace efforts:

- Because of their value in the complex development and dynamic environment of violence and conflict beyond the traditional high level or state level;

- Because of their promotion of trust between the international and the local in rehabilitation of post-conflict societies; and

- As an opportunity to deepen localization beyond contracting local actors and rather understand peace objectives through the eyes and what is considered the everyday life experiences of the people most affected. ${ }^{9}$

The prominence of the local melds two main dimensions of the peacebuilding agenda, that is, to improve general effectiveness of international interventions and institutions of peacebuilding and to promote a normative reflection by encouraging local buy-in and legitimacy in sustaining peacebuilding efforts.

In South Sudan, the 2013 conflict was aggravated by various historical grievances, cumulative of community and ethnic cleavages, party fragmentation, neo-patrimonialism as an excerpt of the liberation struggle, corruption, militarized society, poor state-society relations, and a lack of community resilience and social cohesion, which created a conducive environment for violence. ${ }^{10}$ Many of these causes were absent in the peacebuilding approaches used. After 5 years of conflict, South Sudan is in transition, attempting to rebuild through a locally owned peace and democratic

4 Stathis N. Kalyvas, "Micro-level studies of violence in civil war: Refining and extending the control-collaboration model," Terrorism and Political Violence 24, no. 4 (2012): 658-668, https://doi.org/10.1080/09546553.2012.701986.

5 Roger Mac Ginty and Oliver P. Richmond, "The local turn in peace building: A critical agenda for peace," Third World Quarterly 34, no. 5 (2013): 763-783, https://doi.org/10.1080/01436597.2013.800750.

6 Tim Murithi, "African approaches to building peace and social solidarity," African Journal on Conflict Resolution 6, no. 2 (2006): 9-33, https://doi.org/10.4314/ajcr.v6i2.39402.

7 Siphamandla Zondi, "African Union approaches to peacebuilding: Efforts at shifting the continent towards decolonial peace," African Journal on Conflict Resolution 17, no. 1 (2017): 105-131, https://www.accord.org.za/ajcr-issues/ african-union-approaches-peacebuilding/.

8 Antonia Does, "Inclusivity and local perspectives in peacebuilding: issues, lessons, challenges," Dag Hammarskjöld Foundation, Geneva Peacebuilding Platform, 2013, https://gsdrc.org/document-library/inclusivity-and-local-perspectives-in-peacebuilding-issues-lessons-challenges/; Timothy Donais and Erin McCandless, "International peace building and the emerging inclusivity norm," Third World Quarterly 38, no. 2 (2017): 291-310, https://doi.org/10.1080/01436597.2016.1191344.

9 Acharya defines localization as a process of idea transmission where the local can borrow foreign ideas and fit them into indigenous traditions and practices and an active construction (through discourse, framing, grafting, and cultural selection) where the foreigner develops significant congruence with local beliefs and practices. "Invest [it] with the characteristics of a particular place." See: Amitav Acharya, "How Ideas Spread: Whose Norms Matter? Norm Localization and Institutional Change in Asian Regionalism," International Organization 58, no. 2 (April 2004): 239-275, https://doi.org/10.1017/S0020818304582024.

10 David J. Francis, "Timing and sequencing of post-conflict reconstruction and peacebuilding efforts in South Sudan," in Building Sustainable Peace: Timing and Sequencing of Post-Conflict Reconstruction and Peacebuilding, eds. Arnim Langer and Graham K. Brown (Oxford: Oxford University Press, 2016), 284-299, https://doi.org/10.1093/acprof:0so/9780198757276.003.0016. 
agenda and a commonly envisioned democratic society through the Revitalized- Agreement of Resolution of conflict in South Sudan (R-ARCSS).

Drawing on a careful examination of the challenges and pitfalls of past peacebuilding efforts in South Sudan, this policy note calls for deeper and more effective relationships with local organizations and communities - such as community groups, faith-based organizations, women and youth groups, traditional leadership, and grassroots organizations and non-governmental institutions-aimed at tackling complex issues as the country attempts to realize peace.

Given the growing importance of everyday life in peacebuilding - that is an indicative of the existence and diversity of communities, where the "the everyday lives of people" is at its most powerful as a critical tool - is slowly altering the nature of peacebuilding processes. This policy note puts forth the following recommendations on how policymakers can leverage the "local" and local peacebuilding approaches to improve outcomes and build sustainable peace through increased levels of legitimacy, accountability, and participation:

- The Revitalized Transitional Government of National Unity (R-TGoNU) should re-engage its cooperation and partnership framework by recalibrating its strategy to ensure inclusive investments in the implementation of the R-ARCSS towards conflict prevention in communities and a thorough consideration of the 5-year National Dialogue Resolution. ${ }^{11}$

- Regional stakeholders should encourage and increase inclusivity of local stakeholders in the current R-ARCSS beyond the observer level in the critical stipulations on the implementation of reparations and the transitional justice framework and mechanisms, and the constitutionmaking under chapter $\mathrm{V}$ and $\mathrm{VI}$, consecutively.

- International NGOs should focus on collaboration with national and sub-national NGOs beyond sub-contractual partnerships and on capacity building and training of South Sudanese NGOs, especially given the travel restrictions due to COVID-19.

\section{Relevance to policy and practice}

Although the concept of local approaches to peacebuilding emerged in the early 2000s, African peacebuilding programs only began to integrate this approach into their practice a decade later. One of the first examples of its use was the adoption of policy on local context and inclusivity in the UN peacebuilding architecture published in 2011. The approach was further developed in 2016 through UNSC Resolution 2282, ${ }^{12}$ which sought to diversify the working methods of the Peacebuilding Commission for greater efficiency in its programming, and then again in their 2020 Peacebuilding Architecture Review on Advancing Local Priorities in Global Action. ${ }^{13}$

This current and rapid progress, under the umbrella of "inclusivity," community ownership, and bottom-up approaches, underlines the growing importance of local voices and perspectives to national, regional, and international peacebuilding actors and policymakers. Given the dwindling effectiveness of top-down approaches that are, in isolation, failing to realize a peace dividend

11 Augustino T. Mayai, "The National Dialogue Final Resolutions: What the Presidency should Do," Africa Portal, January 19, 2021, https://www.africaportal.org/publications/national-dialogue-final-resolutions-what-presidency-should-do/.

12 UN Security Council, Resolution 2282, S/RES/2282, April 27, 2016, https://undocs.org/S/RES/2282(2016).

13 A key opportunity for peacebuilding in 2020 was the 2020 Peacebuilding Architecture Review. See: "2020 Peacebuilding Architecture Review: Advancing Local Priorities in Global Action," Global Partnership for the Prevention of Armed Conflict, 2020, accessed October 7, 2021, https://www.gppac.net/2020-peacebuilding-architecture-review-advancing-local-priorities-global-action. 
and constantly facing challenges of the dynamic development of the guerrilla-like asymmetrical character of civil and communal conflict in Africa, the need for change is pressing. Whether it is invoked in debates about post-liberal peace, local ownership, traditional institutions, hybridity, or resistance against international intervention, the "local"14 haunts peacebuilding.

Given the growing calls for engagement and local ownership, vertical linkages have developed between national, sub-national, and communal conflicts and their relationship to national peace processes, which require concerted efforts on the part of international, national, and local level peacebuilding actors to avoid renewed conflict cycles. ${ }^{15}$ Thus, exclusion of the "local voices" in formal peacebuilding processes isolates the very foundations that peace should be built upon.

\section{Healing through shared identities}

The peacebuilding process in South Sudan (2005-2013) was largely led by external intervention with little to minimal inclusive approaches. The cleavages in the pre-2013 peacebuilding efforts are observed in the focus of state building interventions, which the renewed conflict brought to a halt in December 2013. ${ }^{16}$ For instance, one of the biggest interventions between 2011 2012 was with the United Nations Mission in South Sudan (UNMISS), whose mandate focused on strengthening the capacity of the Government of South Sudan and strengthening the rule of law under the overall principle of national ownership. ${ }^{17}$ UNMISS's approach focused on bilateral high-level intervention between government signatories and international monitors, resulting in a disconnect with local citizens. ${ }^{18}$ Their efforts were, however, suspended due to the outbreak of violence sparked by the factionalism within the Sudan People's Liberation Movement (SPLM).

UNMISS's failure resonates with the conflict resolution strategy that culminated in the 2005 Comprehensive Peace Agreement (CPA) (between the North and South of Sudan); the Agreement of Resolution of Conflict in South Sudan (ARCSS) in 2015- which was set back by the 2016 relapse in violence-subsequently restored in the 2018 Revitalized-ARCSS. These peace processes have focused on high-level discussions with the belligerent parties, most notably between Sudanese Armed Forces (SAF)-before secession, the Sudan People's Liberation Movement/Army-in Government (SPLM/A) - and the Sudan People's Liberation Movement/Army-in opposition (SPLM/ A-IO) and other high-level signatories. These processes have often been initiated, conducted, and enforced by international and regional players, such as the Intergovernmental Authority on Development (IGAD), IGAD-Plus Troika countries (US, UK, and Norway), the European Union, and the African Union. The South Sudanese conflict is complex, multi-dimensional, and traverses various societal levels. As such, it cannot be solved by the two warring parties alone. A lasting

14 The "local" is put in inverted commas to emphasize the floating significations and ambiguity of the term in scholarly and practical use. In the following, the local will be defined according to the constraints and use of the paper.

15 Jana Krause, "Stabilization and local conflicts: communal and civil war in South Sudan," Ethnopolitics 18, no. 5 (2019): 478-49, https://doi.org/10.1080/17449057.2019.1640505.

16 Arnim Langer and Graham K. Brown, eds., Building Sustainable Peace: Timing and Sequencing of Post-Conflict Reconstruction and Peacebuilding (Oxford: Oxford University Press, 2016), https://doi.org/10.1093/acprof:0so/9780198757276.003.0005.

17 United Nations Peacebuilding Fund, accessed March 14, 2011, http://www.unpbf.org/countries/southsudan/; "Background," United Nations Mission in South Sudan, accessed October 6, 2021, https://unmiss.unmissions.org/background.

18 Salman M. A. Salman, "The new state of South Sudan and the hydro-politics of the Nile Basin," Water International 36, no. 2 (2011): 154-166, https://doi.org/10.1080/02508060.2011.557997. 
solution to the crisis needs to come from a holistic and inclusive process involving all stakeholders.

Arguably, the 2018 R-ARCSS peace agreement process adopted a broader approach by including refugees, women, youth, South Sudanese religious groups, and traditional leaders to engage with and observe the development of the peace agreement, leading to the formation of the Revitalized Transitional Government of National Unity (R-TGoNU) on February 22, 2020. However, there is doubt among civil society and various local camps that this notion of inclusivity was holistically and successfully implemented beyond the observer level.

Through the years, the fundamental failure of peacebuilding in South Sudan has been marked by a lack of transformation of violent tensions. These tensions manifested both at the top level between the two principals and at the bottom, community level. It is at the lower level where the necessary linkages between communal violence and national security were sparse, ${ }^{19}$ given occurrences prompted by cattle raids, land disputes, and high levels of militarization and politicization of chiefs or other local governance actors in such areas as Bahr el Ghazal, Unity and Lakes States that significantly contributed to the spread and perpetuation of the civil war.

\section{Why the turn to bottom-up peace?}

Despite numerous peace agreements, the return to conflict has confirmed the fragility of this peace. The inadequacies of the democratization approach expose the gap between the political elites (or the decision-makers) and the citizens, who are often thought of as recipients of, rather than participants in, peace.

The dynamic reality of the South Sudan civil conflict and intrastate conflict is marked by a trend in which "The fighters are usually drawn from numerous political factions with divergent agendas, lines of command are blurred or non-existent, and the battlefields are the very towns and villages where the combatants live." 20

It is clear in South Sudan now that the violence is a volatile mix of local, interethnic, and intraethnic conflict infused with political maneuverings on a national and sub-national level. Other issues, such as cattle raids, attacks on traders, attacks on returnees and other violence, can also be indirectly related, and significantly so, to South Sudan dynamics, in which the violence plays out on the local stage.

Fundamentally, issues of local ownership, emancipation, and sustainability in peacebuilding are brought into focus. From this perspective, there is a need to engage with the non-liberal subjects, especially ones without access to institutions of liberal peace. This is with a proposed comprehensive view and a grassroots approach, with women, youth, local community leaders, traditional healers, and provincial leaders, NGOs, and international players taking part in creating peace, with an emphasis on strengthening relationships among the involved parties through psychological, spiritual, social, economic, and political dimensions of society. ${ }^{21}$

19 Krause, "Stabilization," 478-493.

20 John Darby, The Effects of Violence on Peace Processes (Washington, DC: United States Institute of Peace, 2001), https://www. usip.org/publications/2001/11/effects-violence-peace-processes.

21 Harriet J. Kidombo, "The role of sport in peace-building," Centre of Peace and Reconciliation Studies, Coventry University, 2012, https://profiles.uonbi.ac.ke/hkidombo/files/annotated bibliography.pdf; Douglas W. Young, "Prescriptive and elicitive approaches to conflict resolution: examples from Papua New Guinea," Negotiation Journal 14, no. 3 (2012): 211-220, https:// doi.org/10.1111/j.1571-9979.1998.tb00161.x. 


\section{Policy implications on local approaches in peacebuilding in South Sudan}

Investing in people-to-people dialogues. Various peacebuilding initiatives in South Sudan have taken a more bottom-up approach. These approaches often depend on the methods used when working towards reconciliation. These community-led processes involve dialogue and tackling truth, justice, and restitution, re-establishing law and order, disarmament and rehabilitation of armed communities, and forgiveness and restitution. ${ }^{22}$ It has been difficult to determine just how successful these efforts have been given the overall political environment in the country, but they hold promise for peacebuilders who recognize the limits of elite bargaining as a primary strategy.

As a strategy, people-to-people dialogues, such as the 1999 Wunlit Conference and the 20172020 National Dialogue, emphasized dialogue and deep understanding over elite negotiation. This opened up a space whereby the communities and their constituents, especially bereaved communities, can directly pursue peace and reconciliation. Notably, they included marginalized groups such as women, youth, and the disabled, who were given the opportunity to participate in high-visibility positions. These discussions unearthed grievances directly from communities, achieving impactful rehabilitation, enhancing judicial accountability, and promoting healthy interethnic cooperation and interaction, especially with the heterogeneity found in South Sudan.

For instance, in Jonglei, cattle raiding has always existed between the six pastoralist communities (Dinka, Nuer, Murle, Anuak, Kajipo, and Jie). Incidents of brutal violence have soared with the elderly, women, and children being killed and mutilated, raising the death toll into the thousands. Unsuccessful attempts to organize civilian disarmament, demobilization, and reintegration (DDR) in 2006 only led to more violence and distrust. ${ }^{23}$ The nature of such problems calls for adaptive peacebuilding styles, such as people-to-people dialogues, in discussing mitigating circumstances of agreement between the communities while transferring ownership to them.

A demonstration of this strategy is the 1999 Wunlit conference, which presented the most comprehensively documented people-to-people local peace conference held in South Sudan during the civil war between North and South Sudan. In the Wunlit conference, traditional authorities from both the belligerent communities of the Dinka and Nuer were gathered to discuss ways to bring peace to their people. The New Sudan Council of Churches (NSCC) married the humanitarian, resource, and cultural interests of the communities. This dialogue was unlike many peace negotiations, in that it set trust-building as a priority and achieved it through reflecting a deep cultural understanding of the communities. Ultimately, the Wunlit people-to-people process included over two thousand members of the community, from both the Dinka and Nuer, who received open community invitations. Participants openly raised the grievances between them and raised solutions that appeased not only the offended individual but the community as a whole.

Following Wunlit, pastures were formally consecrated for joint use, and Nuer and Dinka cattle

22 John Young, "Sudan IGAD peace process: an evaluation," Sudan Tribune, May 30, 2007, https://constitutionnet.org/sites/ default/files/Young\%20lgad in Sudan Peace Process.pdf.

23 John Ashworth and Maura Ryan, "'One Nation from Every Tribe, Tongue, and People': The Church and Strategic Peacebuilding in South Sudan," Journal of Catholic Social Thought 10, no. 1 (2013): 47-67, https://doi.org/10.5840/jcathsoc20131014. 
were put to graze together. People who left their villages returned, and planting started. These steps were maintained by a peace committee constituted as a custodian of the peace that would not only follow up implementation and sanction violations but also "take the peace home" by popularizing the contents and spirit of the peace agreement(s) at the grassroots level.

Similarly, the National Dialogue (launched in May 2017 and concluded in December 2020) was another space where citizens could take part in the national reconciliation process, in hopes of achieving some tangible development progress to demonstrate the government's responsiveness to citizen expectations. This National Dialogue process involved a 100-member steering committee, which conducted multi-level consultations underscoring causes of the current violent conflict, with different stakeholders at different levels throughout the counties and states of South Sudan. It aimed to address the complexities of South Sudan's conflict through linking the national, regional, and grassroots levels in an effort to curb the civil war. ${ }^{24}$ Generally, national dialogues have been an effective tool, which has not only highlighted the weaknesses of a narrow, top-down approach but has also highlighted the consequences of excluding bottom-up approaches to peacebuilding. ${ }^{25}$ The National Dialogue Steering Committee (NDSC) published its concluding report regarding the National Dialogue process, bringing to light issues, and providing recommendations for the Transitional Government and the Presidency in particular, to work towards peaceful resolutions between the state and the citizens and citizens themselves. These resolutions could offer a policy roadmap for the way forward. ${ }^{26}$

Including middle-level local and international actors. The "local" does not only manifest at the bottom level. South Sudan presents a complex picture when it comes to middle-level actors and the need for integration of strategies. Many international non-governmental organizations (INGOs) have adapted their approaches to build on, facilitate, and support the work of local NGOs, actors, and processes by increasing the participation and inclusion of local youth and women's groups from various provinces into its decision-making and conflict resolution processes, especially in the current implementation of the R-ARCSS. ${ }^{27}$

There is, however, great disagreement among external interveners about the degree to which local, traditional authorities, NGOs, and other representatives of local populations have been included in the development, implementation, monitoring, and evaluation of peacebuilding activities. This speaks to the degree of the cooperation and partnership between International Non-governmental Organizations and South Sudanese NGOs (SSNGOs), which, despite having improved over the years, still lacks meaningful partnership that fosters productive cooperation observed by the external, as well as the internal, actors and organizations of peace in South Sudan. ${ }^{28}$ This weakness has resulted in reduction of the areas of overlap, collaboration, and opportunity, and has increased chances of gaps and challenges for building peace as a common objective.

24 Francis M. Deng, "Sudan: A Nation in Turbulent Search of Itself," The Annals of the American Academy of Political and Social Science 603, no. 1 (2006): 155-162, https://doi.org/10.1177/0002716205283021.

25 Emmaculate Asige Liaga and Cori Wielenga, "Social Cohesion From the Top-Down or Bottom-Up? The Cases of South Sudan and Burundi," Peace \& Change 45, no. 3 (2020): 389-425, https://doi.org/10.1111/pech.12424.

26 Augustino T. Mayai, "The National Dialogue Final Resolutions."

27 Emmaculate Asige Liaga, "The local turn in peacebuilding: A critical analysis of peacebuilding strategies in South Sudan," PhD diss., University of Pretoria, 2019.

28 Lydia Tanner and Leben Moro, "Missed Out: The role of local actors in the humanitarian response in the South Sudan conflict," Oxfam, April 28, 2016, https://doi.org/10.21201/2016.606290. 
There are observable differences in the type and capacity of various projects carried out by international and local peace actors. The challenge is the lack of progress due to the insufficient capacity of local actors to operate at the same level as their external partners. While the international organizations apply a national focus, the local organizations tend to be on a smaller scale and practice what is known as active citizenry.

Due to lower financial and administrative capacity, in most cases SSNGOs form implementation partnerships with INGOs. However, most of the project designs and funding designs are still held and driven by INGOs. Thus, these partnerships lack ownership by the South Sudanese partner organizations. INGOs still mainly follow a liberal model, constantly resisting calls for greater agency and ownership of civil society in South Sudan. This has led to susceptibility of SSNGOs to being co-opted by the norms and ideas of INGOs, as international actors provide ready-made projects to be implemented through a grant or funding application.

Further, through the instruments of funding, this interaction has resulted in a co-optation of local actors in order to adjust to inflexibility of funding, forcing SSNGOs to change and adapt to the structures of international donors. As a result, there is not sufficient time and space spent on peacebuilding interventions that can bring about change. This turns the idea of peacebuilding into projects with little connection to the people they are supposed to help, presenting one of the most substantial challenges among middle-level actors in South Sudan.

Although local and global identities in South Sudan are not mutually exclusive, and their development forms part of a complex system with overlapping identities, a power hierarchy still exists between INGOS and SSNGOs. South Sudan does not present a hybrid space, which denotes international-local interplay, in which there is a balanced cooperation between international and local norms and actors.

\section{Recommendations}

Ensuring sustainable peace through peacebuilding projects that develop effective relationships with local organizations and communities will require action on the part of the international community, the Government of South Sudan, and local actors.

\section{For the Revitalised Government of South Sudan (R-TGoNU)}

The R-TGoNU should ensure inclusive investments in the implementation of the R-ARCSS, conflict prevention and mediation of local level conflicts among communities through a cooperation and partnership framework. This should include participation of local leaders, especially those with influence on community-based armed groups.

The R-TGoNU should also revitalize the 2020 recommendations concluded by the National Dialogue committee. The National Dialogue was based on the notion of inclusivity; the R-TGoNU should consider further development of such channels to encourage inclusive and open discussion. Given the importance of the inclusion of marginalized voices in encouraging the buy-in of peace at the local level, the R-TGoNU should strive to create political space for open dialogue. This could be done by identifying local leaders, peace actors and processes, and by actively engaging them in the National Dialogue as representatives of their communities. 


\section{For international governmental actors}

Restructure peacebuilding interventions to establish links with local organizations. Most international actors' engagement in peacebuilding is tilted in favor of elites, forgetting the potential power of local actors. The gap between international actors and the local can lead to misrepresentation, or no representation, of local grievances in strategies formed by international organizations. Fostering dialogue could bridge this gap. International actors can more thoroughly consult with local organizations in South Sudan. Consultations with genuine, open, and continual dialogue will promote the exchange of ideas and further collaboration to develop bottomup peacebuilding approaches. The decentralization of peace initiatives will help to transfer responsibility for peacebuilding from political elites to grassroots and local actors, further allowing for more effective and tailored processes.

Regional stakeholders should include local stakeholders in peace processes. Given the peace agreement negotiated in 2015 and 2018 by IGAD member countries, IGAD-Plus, they now must consider bringing local groups to the table as participatory members instead of just observers. The engagement of the "local" will not only ensure group ownership of the peace agreement but also facilitate citizens putting pressure on the government to uphold the agreement. Local groups should represent youth, women, civil society, religious groups, traditional leaders from key areas (especially areas with active conflict), local government, and parliamentarians. These local groups can fill important roles in the revitalization process, including direct representation, consultation, observation, and participation.

\section{For international governmental actors}

Focus efforts on building and strengthening the capacity of local actors to build genuine partnerships: INGOs could effectively use their financial resources to help build the capacity of local groups, especially in states with active conflict, including Jonglei, Lakes, and Unity. In some instances, relationships between INGOs and local NGOs in South Sudan are characterized by paternalism. More could be done to develop meaningful partnerships that involve the exchange of ideas and skills, with the intent of external organizations implementing projects that also include existing local ideas and methods. INGOs need to recognize the efforts of local peace initiatives as potential project starting points and foundations, rather than introducing new and foreign, unknown programs and strategies.

\section{For South Sudanese NGOs}

South Sudanese NGOs should coordinate through the available unions and forums, such as through the South Sudan NGO Forum. Through these forums, NGOs can better coordinate and jointly articulate their programs to further strengthen their leverage in complex peacebuilding funding mechanisms. 


\section{List of Acronyms}

ARCSS

CPA

CPA

DDR

IGAD

IGAD-Plus,

INGOS

NDSC

NGOs

NSCC

R-ARCSS

R-TGoNU

SAF

SPLM

SPLM/A

SPLM/A-IO

SSNGO

UN

UNMISS

UNSC
Agreement of Resolution of Conflict in South Sudan

Comprehensive Peace Agreement

Comprehensive Peace Agreement

disarmament, demobilization, and reintegration

Intergovernmental Authority on Development

Intergovernmental Authority on Development- Plus

International Non-Governmental Organizations

National Dialogue Steering Committee

Non-Governmental Organizations

New Sudan Council of Churches

Revitalized- Agreement of Resolution of conflict in South Sudan

The Revitalized Transitional Government of National Unity

Sudanese Armed Forces

Sudan People's Liberation Movement.

Sudan People's Liberation Movement/Army-in Government

Sudan People's Liberation Movement/Army-in opposition

South Sudanese Non-Governmental Organizations

United Nations

United Nations Mission in South Sudan

United Nations Security Council 


\section{Suggested further reading}

\section{On Peacebuilding in Africa}

Harris, David. "The state of peacebuilding in Africa: lessons learned for policymakers and practitioners." International Affairs 97, no. 4 (2021): 1272-1274. https://doi.org/10.1093/ia/iiab107.

Ofuho, Cirino Hiteng. "Community conflict resolution and reconciliation in the Kidepo, Valley of Eastern Equatoria, South Sudan: Some lessons from grassroot practices of peacemaking." In All-Africa Conference on African Principles of Conflict Resolution and Reconciliation, 1999.

\section{On Local Perspectives and Inclusivity in Peacebuilding}

Does, Antonia. "Inclusivity and local perspectives in peacebuilding: issues, lessons, challenges." Dag Hammarskjöld Foundation, Geneva Peacebuilding Platform, 2013. https://gsdrc.org/document-library/ inclusivity-and-local-perspectives-in-peacebuilding-issues-lessons-challenges/.

Leonardsson, Hanna, and Gustav Rudd. “The 'local turn' in peacebuilding: a literature review of effective and emancipatory local peacebuilding." Third World Quarterly 36, no. 5 (2015): 825-839. https://doi.org/10.1080/01436597.2015.1029905.

Gruener, Sigrid, Henrik Person, and Sarah Smith. "Inclusivity in Peacebuilding." Dag Hammarskjöld Foundation, 2014. http://www. daghammarskjold.se/wp-content/uploads/2014/08/dd-paper no6-web.pdf.

Verkoren, Willemijn, and Mathijs Van Leeuwen. "Civil society in peacebuilding: Global discourse, local reality." International Peacekeeping 20, no. 2 (2013): 159-172. https://doi.org/10.1080/13533312.2013.791560.

Akol, Z. D. "Inclusivity: A challenge to the IGAD-led South Sudanese peace process." The Sudd Institute, December 7, 2014. https:// www.suddinstitute.org/publications/show/inclusivity-a-challenge-to-the-igad-led-south-sudanese-peace-process.

Murithi, Timothy. "Practical peacemaking wisdom from Africa: Reflections on Ubuntu." The Journal of Pan African Studies 1, no. 4 (2006): 25-34.

\section{On post-liberal peacebuilding in South Sudan}

African Research and Resource Forum. "Re-Thinking Inclusive Governance in South Sudan." 2015. http://hdl.handle. net/10625/55328.

Omeje, Kenneth, ed. Peacebuilding in Contemporary Africa: In Search of Alternative Strategies. Routledge, 2018. https://doi. org/10.4324/9781351031462.

Da Costa, Diana Felix. "Contextualising liberal peacebuilding for local circumstances: UNMISS and local peacebuilding in South Sudan." Journal of Peacebuilding \& Development 7, no. 2 (2012): 53-66. https://doi.org/10.1080/15423166.2012.743814.

\section{On Local Strategies to Peacebuilding in South Sudan}

Karlsrud, John, and Diana Felix Da Costa. "Moving towards local level peacebuilding? Contextualizing early peacebuilding activities to local circumstances: South Sudan case-study field report." Security in Practice 5 (2012). https://nupi.brage.unit.no/ nupi-xmlui/handle/11250/276452?locale-attribute=en.

Liaga, Emmaculate Asige, and Cori Wielenga. "Social Cohesion From the Top-Down or Bottom-Up? The Cases of South Sudan and Burundi." Peace \& Change 45, no. 3 (2020): 389-425. https://doi.org/10.1111/pech.12424.

Ashworth, John. "The Attempts of Dialogue in Sudan." In Dialogue and Conflict Resolution, edited by Pernille Rieker and Henrik Thunepp, 179-200. Routledge, 2016. https://doi.org/10.4324/9781315576961-12. 


\section{On Local Strategies to Peacebuilding in South Sudan}

Machar, Benjamin. Building a culture of peace through dialogue in South Sudan. Sudd Institute, 2015.

Bahemuka, Augustine. "Non-Violent Religious Militancy: Revisiting the Church-led People-to-People Peacemaking Approach in Southern Sudan." Hekima Institute of Peace Studies \& International Relations, January 2021. http://dx.doi.org/10.13140/ RG.2.2.20232.14084.

Agwanda, Titus, and Geoff Harris. "People-to-people peacemaking and peacebuilding: A review of the work of the New Sudan Council of Churches." African Security Studies 18, no. 2 (2009): 42-52. https://doi.org/10.1080/10246029.2009.9627527.

\section{On National Dialogue in South Sudan}

Mayai, Augustino T. "The National Dialogue Final Resolutions: What the Presidency should Do." Africa Portal, January $19,2021$. https://www.africaportal.org/publications/national-dialogue-final-resolutions-what-presidency-should-do/.

Vhumbunu, Clayton Hazvinei. "The National Dialogue Initiative in South Sudan." Conflict Trends 2018, no. 1 (2018). https://hdl. handle.net/10520/EJC-ecff04924.

Deng, Francis. "National Dialogue: A Critical Perspective." The Sudd Institute, 2017. https://reliefweb.int/sites/reliefweb.int/files/ resources/595d3c425be3b TheNationalDialogueStrategy Full.pdf.

\section{On Youth and Women of South Sudan and Peacebuilding}

Chilvers, Richard. "Preventing Cattle Raiding Violence in South Sudan: Local level peace building focusing on young people." Oxfam, August 2016. https://policy-practice.oxfam.org/resources/preventing-cattle-raiding-violence-in-south-sudan-local-levelpeace-building-fo-617936/.

Godia, Jane. "Sudanese women balancing the delicate political act." South Sudan Women's Agenda, August 2009. http://www. awcfs.org/dmdocuments/gem sudan/SudanWomenAgenda.pdf.

Manchanda, Rita. "Women's agency in peace building: Gender relations in post-conflict reconstruction." Economic and Political Weekly 40, no. 44-45 (2005): 4737-4745. https://www.jstor.org/stable/4417360.

Isike, Christopher, and Ufo Okeke Uzodike. "Towards an indigenous model of conflict resolution: Reinventing women's roles as traditional peacebuilders in neo-colonial Africa." African Journal on Conflict Resolution 11, no. 2 (2011): 32-58. https://doi. org/10.4314/ajcr.v11i2.69832.

Ajak, Peter Biar. "Youth-led national dialogue the only option to avert disaster in South Sudan." Brookings Institution, October 12, 2016._https://www.brookings.edu/blog/africa-in-focus/2016/10/12/ youth-led-national-dialogue-the-only-option-to-avert-disaster-in-southsudan/.

Mayen, Apuk Ayuel. Women in peace making processes in South Sudan. Sudd Institute., 2013. https://www.suddinstitute.org/ publications/show/women-in-peace-making-processes-in-south-sudan. [Accessed May 18, 2018]. 


\section{Bibliography}

Acharya, Amitav. "How Ideas Spread: Whose Norms Matter? Norm Localization and Institutional Change in Asian Regionalism." International Organization 58, no. 2 (April 2004): 239-275. https://doi.org/10.1017/S0020818304582024.

Ashworth, John, and Maura Ryan. "'One Nation from Every Tribe, Tongue, and People': The Church and Strategic Peacebuilding in South Sudan." Journal of Catholic Social Thought 10, no. 1 (2013): 47-67. https://doi.org/10.5840/jcathsoc20131014.

Darby, John. The Effects of Violence on Peace Processes. Washington, DC: United States Institute of Peace, 2001. https://www.usip. org/publications/2001/11/effects-violence-peace-processes.

Deng, Francis M. "Sudan: A Nation in Turbulent Search of Itself." The Annals of the American Academy of Political and Social Science 603, no. 1 (2006): 155-162. https://doi.org/10.1177/0002716205283021.

Does, Antonia. "Inclusivity and local perspectives in peacebuilding: issues, lessons, challenges." Dag Hammarskjöld Foundation, Geneva Peacebuilding Platform, 2013. https://gsdrc.org/document-library/ inclusivity-and-local-perspectives-in-peacebuilding-issues-lessons-challenges/.

Donais, Timothy, and Erin McCandless. "International peace building and the emerging inclusivity norm." Third World Quarterly 38 , no. 2 (2017): 291-310. https://doi.org/10.1080/01436597.2016.1191344.

Francis, David J. "Timing and sequencing of post-conflict reconstruction and peacebuilding efforts in South Sudan." In Building Sustainable Peace: Timing and Sequencing of Post-Conflict Reconstruction and Peacebuilding, edited by Arnim Langer and Graham K. Brown, 284-299. Oxford: Oxford University Press, 2016. https://doi.org/10.1093/acprof:oso/9780198757276.003.0016.

Global Partnership for the Prevention of Armed Conflict. "2020 Peacebuilding Architecture Review: Advancing Local Priorities in Global Action." Accessed October 7, 2021. https://www.gppac.net/2020-peacebuilding-architecture-review-advancing-localpriorities-global-action.

Hirblinger, Andreas T., and Claudia Simons. "The good, the bad, and the powerful: Representations of the 'local' in peacebuilding." Security Dialogue 46, no. 5 (2015): 422-439. https://doi.org/10.1177/0967010615580055.

Kalyvas, Stathis N. "Micro-level studies of violence in civil war: Refining and extending the control-collaboration model." Terrorism and Political Violence 24, no. 4 (2012): 658-668. https://doi.org/10.1080/09546553.2012.701986.

Kidombo, Harriet J. "The role of sport in peace-building." Centre of Peace and Reconciliation Studies, Coventry University, 2012. https://profiles.uonbi.ac.ke/hkidombo/files/annotated bibliography.pdf.

Krause, Jana. "Stabilization and local conflicts: communal and civil war in South Sudan." Ethnopolitics 18, no. 5 (2019): $478-49$. https://doi.org/10.1080/17449057.2019.1640505.

Langer, Arnim, and Graham K. Brown, eds. Building Sustainable Peace: Timing and Sequencing of Post-Conflict Reconstruction and Peacebuilding. Oxford: Oxford University Press, 2016. https://doi.org/10.1093/acprof:oso/9780198757276.003.0005.

Liaga, Emmaculate Asige, and Cori Wielenga. "Social Cohesion from the Top-Down or Bottom-Up? The Cases of South Sudan and Burundi." Peace \& Change 45, no. 3 (2020): 389-425. https://doi.org/10.1111/pech.12424.

Liaga, Emmaculate Asige. "The local turn in peacebuilding: A critical analysis of peacebuilding strategies in South Sudan." PhD diss., University of Pretoria, 2019.

Mac Ginty, Roger, and Oliver P. Richmond. "The local turn in peace building: A critical agenda for peace." Third World Quarterly 34 , no. 5 (2013): 763-783. https://doi.org/10.1080/01436597.2013.800750.

Mayai, Augustino T. "The National Dialogue Final Resolutions: What the Presidency should Do." Africa Portal, January 19, 2021. https://www.africaportal.org/publications/national-dialogue-final-resolutions-what-presidency-should-do/.

Murithi, Tim. "African approaches to building peace and social solidarity." African Journal on Conflict Resolution 6, no. 2 (2006): 9-33. https://doi.org/10.4314/ajcr.v6i2.39402.

Sabaratnam, Meera. "Avatars of Eurocentrism in the Critique of the Liberal Peace." Security Dialogue 44, no. 3 (2013): $259-278$. https://doi.org/10.1177/0967010613485870. 
Salman, Salman M. A. "The new state of South Sudan and the hydro-politics of the Nile Basin." Water International 36, no. 2 (2011): $154-166$. https://doi.org/10.1080/02508060.2011.557997.

Tanner, Lydia, and Leben Moro. "Missed Out: The role of local actors in the humanitarian response in the South Sudan conflict." Oxfam, April 28, 2016. https://doi.org/10.21201/2016.606290.

UN Security Council. Resolution 2282, S/RES/2282. April 27, 2016. https://undocs.org/S/RES/2282(2016).

United Nations Mission in South Sudan. "Background." Accessed October 6, 2021. https://unmiss.unmissions.org/background.

United Nations Peacebuilding Fund. Accessed March 14, 2011. http://www.unpbf.org/countries/southsudan/.

Van Leeuwen, Mathijs, Joseph Nindorera, Jean-Louis Kambale Nzweve, and Corita Corbijn. "The 'local turn' and notions of conflict and peacebuilding-Reflections on local peace committees in Burundi and eastern DR Congo." Peacebuilding 8, no. 3 (2020): 279-299. https://doi.org/10.10 $\underline{80 / 21647259.2019 .1633760 .}$.

Young, Douglas W. "Prescriptive and elicitive approaches to conflict resolution: examples from Papua New Guinea." Negotiation Journal 14, no. 3 (2012): 211-220. https://doi.org/10.1111/j.1571-9979.1998.tb00161.x.

Young, John. "Sudan IGAD peace process: an evaluation." Sudan Tribune, May 30, 2007. https://constitutionnet.org/sites/default/files/Young\%20 Igad in Sudan Peace Process.pdf.

Zondi, Siphamandla. "African Union approaches to peacebuilding: Efforts at shifting the continent towards decolonial peace." African Journal on Conflict Resolution 17, no. 1 (2017): 105-131. https://www.accord.org.za/ajcr-issues/african-union-approaches-peacebuilding/. 


\section{About the Note}

Author: Emmaculate Asige Liaga

Emmaculate Asige Liaga is an associate post-doc researcher at the Centre for African Studies, University of Basel, and a visiting researcher at the Centre for Conflict, Development and Peacebuilding (CCDP), Graduate Institute Geneva. Her work is on the analysis of conflict resolution mechanisms and nexus of local and adaptive approaches in intervention of peacebuilding in Africa. Emmaculate is also a senior researcher at the Centre for Conflict and Peace Africa (CCPA), South Africa, where she conducts policy research on peacebuilding in Africa. She is a former Woodrow Wilson Centre Southern Voices Network for Peacebuilding Scholar (2017), a Next Generation Social Sciences fellow, and a former Chevening Scholar (2015/2016). She is a holder of a Doctoral degree (2020) from the University of Pretoria (in conjunction with the University of Basel). She graduated from the University of Manchester with a master's in international security studies (2016), and obtained her undergraduate degree (2014) from Pretoria. Her research interests include peace and security from below, conflict resolution, agency of communities in policymaking, and international relations theories (critical theories and marginalized theories).

The views expressed in this publication are those of the authors. They do not necessarily reflect the views of the RESOLVE Network, the U.S. Institute of Peace, or any entity of the U.S. government.

RESOLVE NETWORK

better research.informed practice.improved policy on violent extremism.

www.resolvenet.org

( 9 in.
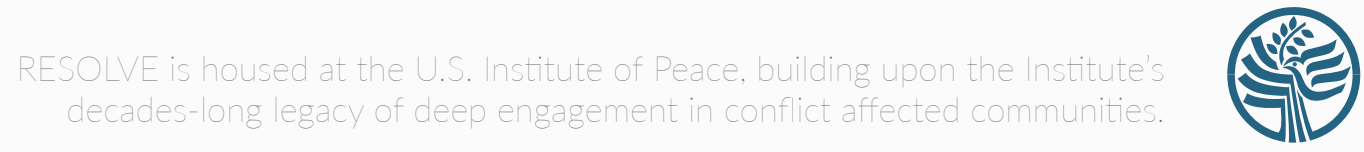

United States

Institute of Peace

Making Peace Possible 